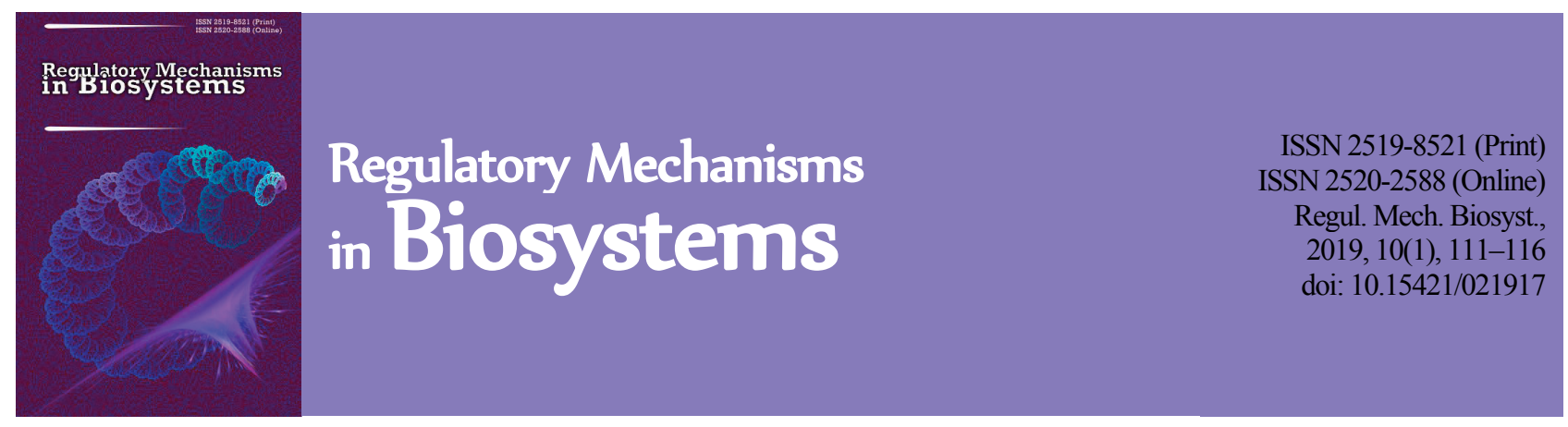

\title{
Influence of fungicides on activities of enzymes of phenolic metabolism in the early stages of formation and functioning of soybean symbiotic apparatus
}

\author{
T. P. Mamenko, Y. O. Khomenko, S. Y. Kots \\ Institute of Plant Physiology and Genetics, National Academy of Sciences of Ukraine, Kyiv, Ukraine
}

Article info

Received 16.02.2019

Received in revised form 20.03.2019

Accepted 21.03.2019

Institute of Plant Physiology and Genetics, National Academy of Sciences

of Ukraine, Vasylkivska st.,

31/17, Kyiv, 03022, Ukraine

Tel.: +38-050-964-17-89.

E-mail:t_mamenko@ukr.net

\begin{abstract}
Mamenko, T. P., Khomenko, Y. O., \& Kots, S. Y. (2019). Influence of fungicides on activities of enzymes of phenolic metabolism in the early stages of formation and functioning of soybean symbiotic apparatus. Regulatory Mechanisms in Biosystems, 10(1), 111-116. doi:10.15421/021917
\end{abstract}

We studied the effect of complex seed treatment with fungicides and rhizobium culture on the activity of phenolic metabolism enzymes - polyphenol oxidase and guaiacol peroxidase in the early stages of the formation and functioning of various symbiotic systems Glycine max - Bradyrhizobium japonicum. In the research we used microbiological, physiological, biochemical methods, gas chromatography and spectrophotometry. The objects of the study were selected symbiotic systems formed with the participation of soybean (Glycine max (L.) Merr.), Diamond variety, strains Bradyrhizobium japonicum 634b (active, virulent) and 604k (inactive, highly virulent) and fungicides Maxim XL 035 PS (fludioxonil, $25 \mathrm{~g} / \mathrm{L}$, metalaxyl, $10 \mathrm{~g} / \mathrm{L}$ ), and Standak Top (fipronil, $250 \mathrm{~g} / \mathrm{L}$, thiophanate methyl, $225 \mathrm{~g} / \mathrm{L}$, piraclostrobin, $25 \mathrm{~g} / \mathrm{L}$ ). Before sowing, the seeds of soybean were treated with solutions of fungicides, calculated on the basis of one rate of expenditure of the active substance of each preparation indicated by the producer per ton of seed. One part of the seeds treated with fungicides was inoculated with rhizobium culture for $1 \mathrm{~h}$ (the titre of bacteria was 108 cells in $1 \mathrm{ml}$ ). The other part of the fungicide-treated seeds was not inoculated by rhizobium culture. As a result of the research, it was revealed that an effective symbiotic system formed with the participation of soybean plants and the active strain rhizobia $634 \mathrm{~b}$ is characterized by a high level of polyphenol oxidase activity and low guaiacol peroxidase in roots and root nodules in the stages of second and third true leaves. Such changes in the activity of enzymes occurred along with the formation of nodules which actively fixed the molecular nitrogen of the atmosphere. An ineffective symbiotic system (strain 604k) is characterized by an elevated level of polyphenol oxidase activity in the roots and guaiacol peroxidase in the root nodules, which is accompanied by activation of the process of nodulation. Treatment of soybean seeds with fungicides in an effective symbiotic system leads to a change in the activity of the enzymes of the phenolic metabolism, which induced adaptive changes in plant metabolism and growth of nitrogenase activity of the root nodules. The recorded changes in the activity of both enzymes for the action of fungicides in the ineffective symbiotic system can be considered as a kind of response of the plant to the treatment and were observed along with the reduction of the processes of nodulation into the stage of the third true leaf.

Keywords: Bradyrhizobium japonicum; legume; polyphenol oxidase; guaiacol peroxidase; nitrogenase activity; symbiotic system; strain.

\section{Introduction}

Symbiosis between nodules bacteria and legumes is based on a complex sequence of morphophysiological changes in partner cells (Laranjo et al., 2014; Argawa et al., 2017; McCormick, 2018). The initial stages of interaction are triggered by a cascade of signals that symbionts exchange with each other, and are accompanied by a series of molecular interactions. The primary signal is the specific phenolic compounds, in particular flavonoids, which are rooted in the rhizosphere and cause chemotaxis and expression of the nodulation genes in rhizobia. In response, the bacteria synthesize lipochitooligosaccharides (Nod-factors) that trigger the development of root nodules (Chang et al., 2009; Desbrosses et al., 2011; Andrews \& Andrews, 2017). It is believed that phenolic compounds act as signal inducers of virulence genes at the moment of interaction between micro and macrosymbionts (Yoruk et al., 2003; Shimizu et al., 2007). The study of the chemical nature of the signaling compounds or inductors of the Nod-genes, which are isolated by the roots of the host plant, was established by their flavonoid nature. In particular, Glycine max (L.) Merr. - Bradyrhizobium japonicum inducers are isoflavones - dadzein and genestein (Kosslak et al., 1987). Oxidation of flavonoids in plants is mainly catalyzed by polyphenol oxidases (catecholoxidases and laccases) and peroxidases (Taranto et al., 2017; Panadare \& Rathod, 2018). The activity of these enzymes is induced both during vegetation of plants and under the influence of environmental stressors, in particular microbial infections - the so-called "pathogenic attacks" (Araji et al., 2014; Mishra et al., 2016). The composition of phenolic compounds and their amount in a plant varies significantly from the moment of infection of legumes, nodule formation and aging (Yoruk et al., 2003; Shimizu et al., 2007). It has been shown that during the growing season of soybean, phenolic compounds accumulate in the tissues, which reaches a maximum during the plant budding stage (Novikova \& Sidorova, 2003; Jemo et al., 2017). Such data testify to their participation both in the processes of general metabolism of plants, and those related to nitrogen fixation, in particular.

In recent years, research has been actively conducted to study the effect of drugs with a fungicidal effect on the effectiveness of legumerhizobium symbiosis (Bikrol et al., 2005; Fox et al., 2007; Araujo et al., 2017; Mikolaevsky et al., 2017; Standish et al., 2018). Scientists note that one of the important factors for protecting soybean plants from diseases and pests is seed treatment with seed disinfectants combined with $B$. japonicum microsymbontive inoculants, which in turn contribute to stress resistance and plant productivity (Mikolaevsky et al., 2017). At the same time, studies have found that drugs with fungicidal activity cause a disturbance of the regulatory signaling system between the macro- and microsymbiont, blocking the activity of the nodulation genes, and decreasing the level of the rhizobial Nod factor (Bikrol et al., 2005; Fox et al., 2007; Araujo et al., 2017). 
One of the most important aspects of the development of legumerhizobium symbiosis is believed to be the macrosymbiont regulation of the early stages of symbiosis: the introduction of rhizobia in root tissue and the initiation of the formation of plant-microbial structures - nodule (Glyanko, 2016; Andrews \& Andrews, 2017; Pradhan et al., 2018). Disclosure of the formation of protective reactions in the symbiosis of legumes with strains of nodules bacteria is important for finding effective symbiotic systems that are able to realize their adaptive potential for the action of stress factors, and the expansion and deepening of research in this direction involves the improvement of existing and the creation of new physiological means of regulating their adaptive ability under stressful conditions.

The aim of the work was to study the effect of complex seed treatment with fungicides and rhizobium culture on the activity of phenolic metabolism enzymes - polyphenol oxidase and guaiacol peroxidase in the early stages of the formation and functioning of various symbiotic systems G. max - B. japonicum.

\section{Materials and methods}

The objects of the study are selected symbiotic systems, formed with participation of soybean (Glycine max (L.) Merr.) Diamond variety, strains Bradyrhizobium japonicum 634b (active, virulent) and 604k (inactive, highly virulent) and fungicides Maxim XL 035 PS (fluvidoxonil, $25 \mathrm{~g} / \mathrm{L}$, metalaxyl, $10 \mathrm{~g} / \mathrm{L}$ ) and Standak Top (fipronil, $250 \mathrm{~g} / \mathrm{L}$, thiophanate methyl, $225 \mathrm{~g} / \mathrm{L}$, piraclostrobin, $25 \mathrm{~g} / \mathrm{L}$ ). We used B. japonicum strains from the museum collection of the Symbiotic Nitrogen Fixation Department of the Institute of Plant Physiology and Genetics of the National Academy of Sciences of Ukraine. Before sowing, soybeans were treated with solutions of fungicides, calculated on the basis of one rate of expenditure of the active substance of each preparation indicated by the producer per ton of seeds.

For research, fungicides were used that differed in the spectrum of action of active substances. In particular, the active ingredients (fipronil, thiophanate-methyl, pyraclostrobin), which are part of Standak Top, combine fungicidal and insecticidal action. Each of these substances has a special mechanism of action, as well as the duration of protective action. In particular, the action of fipronil consists in blocking gamma-aminobutyric acid, which regulates the passage of the nerve impulse through chlorine channels in the membranes of the nerve cells, causing a violation of the function of the nervous system of insects. Pyraclosterobin interferes with mitochondrial breathing, blocking the transport of electrons, and violates the energy exchange in a fungus cell. Thiophanatemethyl suppresses the formation of ergosterol, as well as the biosynthesis of nucleic acids in fungal cells (www.demetra-agra.com.ua).

The fungicide Maxim XL contains two active ingredients (fludioxonil and metalaxyl), one of which, fludioxonil, is an analogue of a natural antibiotic, is excreted by soil bacteria Pseudomonas pyrocinia, which inhibit the growth of pathogenic fungi. Influence of substances of the subclass of triazolintion on the growth and reproduction of the pathogen is associated with a violation of the function of cell membranes (www.demetra-agra.com.ua).

One part of the seeds treated with fungicides was inoculated with suspension of rhizobium culture for 1 hour. The culture of rhizobium was grown on solid mannitol - yeast medium for 9 days at $26-28^{\circ} \mathrm{C}$ (the titer of bacteria was 108 cells in $1 \mathrm{ml}$ ). The other part of fungicidetreated seeds was not inoculated by rhizobium culture.

Plants were grown in sand pots in the application of a nutritional mixture of Gelrigel with 0.25 nitrogen rates from natural light and optimal water supply ( $60 \%$ of full water capacity). For research, soybean roots were selected in the early stages of ontogenesis - seedling leaves, primordial leaves, first true leaf, second true leaf, and root nodules in the stage of third true leaf. The control options were: non-inoculated plants without fungicide treatment, and plants inoculated with strains $634 \mathrm{~b}$ and $604 \mathrm{k}$ without using fungicide treatment.

The nodulation ability of $B$. japonicum was determined by counting the number and mass of root nodules. Nitrogenase activity (acetylene reduction activity) of intact plants was measured on gas chromatograph "Agilent GC system 6850" (USA) with flame-ionization detector (Har- dy, 1968). The separation of gases was carried out on a column (Supelco Porapak N) at a thermostat temperature of $55^{\circ} \mathrm{C}$ and a detector $-150^{\circ} \mathrm{C}$. The carrier gas was helium $(20 \mathrm{ml}$ per 1 minute). The volume of the analyzed sample of the gas mixture was $1 \mathrm{~cm}^{3}$. As a standard, pure ethylene (Sigma-Aldrich, No. 536164, USA) was used.

To obtain the enzyme extract, the weight of the plant material $(1: 2)$ was homogenized with a cooled $60 \mathrm{mM}$ phosphate buffer $(\mathrm{pH} 7.5)$ containing $2 \mathrm{mM}$ ethylenediaminetetraacetic acid, $1 \mathrm{mM}$ phenylmethylsulfonyl fluoride, $5 \mathrm{mM} \beta$-mercaptoethanol and $1 \%$ polyvinylpyrrolidone. The homogenate was centrifuged at $10,000 \mathrm{rpm}$ for 20 minutes at $4{ }^{\circ} \mathrm{C}$. The supernatant was used to determine the activity of enzymes using the Smart Spec Plus spectrophotometer (USA).

Guaiacol peroxidase activity (EC 1.11.1.7) was determined by the increase in optical density at $470 \mathrm{~nm}$ for a minute as a result of oxidation of guaiacol (extinction coefficient $\varepsilon=26.6 \mathrm{mmol}^{-1} \mathrm{~cm}^{-1}$ ) (Egley, 1983). The reaction mixture contained $60 \mathrm{mM}$ potassium phosphate buffer (pH 7.0), $0.1 \mathrm{mM}$ ethylenediaminetetraacetic acid, $0.5 \%$ guaiacol, $100 \mathrm{mM}$ hydrogen peroxide. The reaction was initiated by the addition of a supernatant. The results are presented in $\mu$ moles of the oxidized guaiacol on the protein concentration ( $\mathrm{mg}$ ) in the supernatant.

Polyphenol oxidase activity (EC 1.10.3.1) - ascending optical density at $420 \mathrm{~nm}$ for a minute in the presence of pyrocatechin (Kamal et al., 2015). The reaction mixture contained $60 \mathrm{mM}$ potassium phosphate buffer (pH 7.4), $0.1 \mathrm{mM}$ ethylenediaminetetraacetic acid, $0.05 \mathrm{M}$ pyrocatechin. The reaction was initiated by the addition a supernatant. The results are presented in units of activity of the enzyme (U) on the concentration of protein $(\mathrm{mg})$ in the supernatant. The content of total soluble protein in the enzyme extract was determined by Bradford (1976).

The results were statistically analyzed in the Statistica 6.0 (Statsoft Inc., USA) program pack. The tables and figures show the arithmetic mean values and their standard errors $(x \pm S E)$. The reliability of the differences between the samples was evaluated using the single-factor dispersion analysis ANOVA. Bonferroni pairwise test was carried out after ANOVA for the determination of significant differences $(\mathrm{P}<0.05)$ between the means of the values obtained for each groups.

\section{Results}

The treatment of soybean seeds with fungicide Maxim XL resulted in an increase in the activity of guaiacol peroxidase in the roots of $99.8 \%$ and $288.2 \%$, respectively in the seedlings and primordial leaves (Table 1). By the action of the Standak Top, the activity of the enzyme decreased by $46.8 \%$ in the stage of seedlings and increased by $436.9 \%$ in the stage of primordial leaves. In the subsequent stages of ontogenesis (first and second true leaves), the activity of guaiacol peroxidase was at the level of untreated plants in both variants using fungicides.

The inoculation of soybean seeds by inactive highly-virulent strain $604 \mathrm{k}$ induced slight changes in the activity of guaiacol peroxidase in the roots in the stages of primordial leaves, the first and second true leaves, as compared to non-ionoculated plants.

The use of pre-sowing treatment of soybean seeds with Maxim XL and Standak Top fungicides together with inoculation of the inactive rhizobia strain $604 \mathrm{k}$ caused a significant increase in the activity of guaiacol peroxidase in the roots in the stages of seedlings and primordial leaves and the first true leaf. In the next stages of ontogenesis (first and second true leaves), the activity of guaiacol peroxidase was fixed at the level of untreated plants in both variants using fungicides.

The inoculation of soybean seeds with the active rhizobia strain $634 \mathrm{~b}$ did not cause changes in the activity of guaiacol peroxidase in soybean roots during the early stages of vegetation to the second true leaf stage, when the enzyme activity decreased by $70.4 \%$ compared to non-inoculated plants. The treatment of seeds with fungicides together with the active strain of $634 \mathrm{~b}$ rhizome led to an increase in the activity of guaiacol peroxidase in the roots in the primidary leaf stage under the action of Maxim XL and in the stage of the first true leaf for the action of the Standak Top, as compared to inoculated plants without processing with fungicides. In the stage of the second true leaf, the activity of the enzyme was reduced by the actions of the Standak Top and did not significantly increase under the actions of Maxim XL. 
Table 1

Influence of fungicides on activities of guaiacol peroxidase in soybean roots inoculated by $B$. japonicum ( $\mathrm{nmol}$ of oxidized guaiacol/mg protein $\cdot \min , \mathrm{x} \pm \mathrm{SE}, \mathrm{n}=5$ )

\begin{tabular}{|c|c|c|c|c|}
\hline \multirow[b]{2}{*}{ Variants } & \multicolumn{4}{|c|}{ Stages of ontogenesis } \\
\hline & $\begin{array}{c}\text { seedlings } \\
\text { leaves }\end{array}$ & $\begin{array}{c}\text { primordial } \\
\text { leaves }\end{array}$ & $\begin{array}{c}\text { first } \\
\text { true leaf }\end{array}$ & $\begin{array}{l}\text { second } \\
\text { true leaf }\end{array}$ \\
\hline Non-inoculated plants & $8.11 \pm 0.56$ & $6.21 \pm 0.57$ & $24.14 \pm 1.62$ & $292.12 \pm 20.44$ \\
\hline Maxim XL & $16.21 \pm 1.13^{* * *}$ & $24.11 \pm 1.68^{* * *}$ & $25.12 \pm 1.73^{*}$ & $322.14 \pm 22.55^{*}$ \\
\hline Standak Top & $4.31 \pm 0.21^{* *}$ & $33.34 \pm 2.34^{* * *}$ & $28.15 \pm 1.28^{*}$ & $278.11 \pm 15.71^{*}$ \\
\hline Strain 634b & $7.22 \pm 0.48^{*}$ & $8.21 \pm 0.62^{*}$ & $24.12 \pm 1.46$ & $86.42 \pm 5.11^{* * * *}$ \\
\hline Maxim XL + strain 634b & $13.14 \pm 1.12^{* * \#}$ & $17.12 \pm 1.32^{* * * \#}$ & $22.15 \pm 1.17^{* \neq}$ & $95.13 \pm 6.43^{* * * \#}$ \\
\hline Standak Top + strain 634b & $8.43 \pm 0.59^{\neq}$ & $12.14 \pm 0.84^{* * * \#}$ & $34.12 \pm 2.41^{* * * \#}$ & $61.15 \pm 4.24^{* * * \#}$ \\
\hline Strain $604 \kappa$ & $5.32 \pm 0.37^{* *}$ & $14.23 \pm 0.98^{* * *}$ & $11.15 \pm 0.78^{* * *}$ & $380.54 \pm 28.61^{* * *}$ \\
\hline Maxim XL + strain 604k & $16.02 \pm 1.23^{* * * \times \times x}$ & $31.12 \pm 2.17^{* * * \times \times x}$ & $32.12 \pm 2.23^{* * * \times x}$ & $310.12 \pm 26.64^{* \times}$ \\
\hline Standak Top + strain $604 \mathrm{k}$ & $8.14 \pm 0.61^{\times x}$ & $19.12 \pm 1.13^{* * * \times x}$ & $35.23 \pm 2.54^{* * * x \times x}$ & $367.12 \pm 22.71^{\text {**x }}$ \\
\hline
\end{tabular}

Note: data compared to the control are reliable at ${ }^{\neq \times}-\mathrm{P}<0.05,{ }^{\# \times \times}-\mathrm{P}<0.01,{ }^{\# \times \times \times} \mathrm{P}<0.001 \quad$ (* $^{*}$ relative to the variant without inoculation, ${ }^{\neq}$and ${ }^{\times}-$relative to the variants with inoculation with strains $634 \mathrm{~b}$ and $604 \mathrm{k}$, respectively).

Table 2

Influence of fungicides on the activities of polyphenol oxidase in soybean roots inoculated by $B$. japonicum $(\mathrm{U} / \mathrm{mg}$ protein $\cdot \min , \mathrm{x} \pm \mathrm{SE}, \mathrm{n}=5)$

\begin{tabular}{|c|c|c|c|c|}
\hline \multirow{2}{*}{ Variants } & \multicolumn{4}{|c|}{ Stages of ontogenesis } \\
\hline & seedlings leaves & primordial leaves & first true leaf & second true leaf \\
\hline Non-inoculated plants & $3.68 \pm 0.22$ & $3.55 \pm 0.25$ & $4.60 \pm 0.27$ & $5.32 \pm 0.32$ \\
\hline Maxim XL & $3.24 \pm 0.19$ & $4.45 \pm 0.26^{*}$ & $5.85 \pm 0.35^{*}$ & $5.61 \pm 0.36$ \\
\hline Standak Top & $5.82 \pm 0.34^{* *}$ & $5.79 \pm 0.34^{* *}$ & $6.14 \pm 0.36^{* *}$ & $7.29 \pm 0.43^{* * *}$ \\
\hline Strain $634 b$ & $6.52 \pm 0.45^{* * *}$ & $3.52 \pm 0.21$ & $3.84 \pm 0.23$ & $4.71 \pm 0.28$ \\
\hline Maxim XL + strain 634b & $4.81 \pm 0.28^{* \#}$ & $5.33 \pm 0.34^{* * \#}$ & $3.89 \pm 0.24$ & $4.47 \pm 0.26^{*}$ \\
\hline Standak Top + strain $634 b$ & $3.91 \pm 0.23$ & $4.95 \pm 0.29^{* * \#}$ & $7.46 \pm 0.44$ & $6.18 \pm 0.37^{* * \#}$ \\
\hline Strain $604 \kappa$ & $4.71 \pm 0.28^{*}$ & $4.02 \pm 0.24$ & $7.25 \pm 0.40^{* * *}$ & $7.71 \pm 0.48^{* * *}$ \\
\hline Maxim XL + strain 604k & $5.35 \pm 0.32^{* *}$ & $4.12 \pm 0.25^{*}$ & $5.37 \pm 0.32^{x \times}$ & $4.11 \pm 0.32^{\mathrm{x} \times}$ \\
\hline Standak Top + strain $604 \mathrm{k}$ & $8.25 \pm 0.51^{* * * \times \times x}$ & $8.11 \pm 0.48^{* * * \times \times x}$ & $8.22 \pm 0.49^{* * *}$ & $5.67 \pm 0.44^{\times \times x}$ \\
\hline
\end{tabular}

Note: see Table 1.

It was established that in plants of non-inoculated soybean, the activity of polyphenol oxidase in the roots increased by $25.3 \%$ and $27.1 \%$ respectively in the stage of primordial leaves and the first true leaf of seeds pretreated with fungicide Maxim XL (Table 2). In the stage of the second true leaf, activity of the enzyme was observed at the level of plants without treatment by fungicides. The Standak Top showed an increase in the activity of the enzyme during the early stages of ontogenesis. Following soybean inoculation with the inactive rhizobia $604 \mathrm{k}$ strain, the activity of polyphenol oxidase increased in the roots, especially in the first (57.6\%) and second (44.9\%) true leaves stages.

Seed treatment by Maxim XL fungicide together with an inoculum (strain 604k) induced a decrease in enzyme activity in the first and second true leaf stage by $25.9 \%$ and $46.6 \%$, respectively, as compared to inoculated plants without processing with fungicides. In the variant with the treatment with Standak Top and an inoculum (strain 604k), an increase in the activity of polyphenol oxidase in the seedlings (75.1\%) and primordial leaves $(101.7 \%)$ was recorded. In the stage of the first true leaf, activity of the enzyme was almost at the level of untreated plants and decreased to $26.4 \%$ in the stage of the second true leaf.

In the symbiotic system formed with the participation of soybeans and the active strain $634 \mathrm{~b}$, the increase in the activity of polyphenol oxidase in the roots by $77.1 \%$ in the stage of seedlings leaves and the approximation of the activity of the enzyme to the level of non-inoculated plants in the subsequent stages of ontogenesis was revealed.

Seed treatment by fungicide Maxim XL together with an inoculant $634 \mathrm{~b}$ induced a decrease in the activity of polyphenol oxidase in the roots in the stage of seedlings leaves (by 26.2\%), an increase in the stage of primordial leaves (by 51.4\%), and an approximation of the activity of the enzyme to inoculated plants in the stages of the first and second true leaves. Standak Top in combination with inoculum (strain 634b), showed a decrease in the activity of polyphenol oxidase in the roots in the stage of the seedlings' leaves (by 40.1\%) and an increase in the activity of the enzyme in the subsequent stages of ontogenesis.

In the stage of third true leaf, the symbiotic system formed with the participation of soybean plants and the active strain rhizobia $634 \mathrm{~b}$ differed by a low level of guaiacol peroxidase activity in root nodules
(20 times) and a high level of polyphenol oxidase activity (3 times), compared to plants inoculated with an inactive strain $604 \mathrm{k}$ (Table 3 ).

\section{Table 3}

Influence of fungicides on activities of enzymes of phenolic metabolism in soybean root nodules inoculated by $B$. japonicum in stage of the third true leaf $(x \pm S E, n=5)$

\begin{tabular}{lcc}
\hline Variants & $\begin{array}{c}\text { Guaiacol peroxidase, } \\
\text { nmol of oxidized } \\
\text { guaiacol/mg protein } \cdot \min \end{array}$ & $\begin{array}{c}\text { Polyphenol oxidase, U/ } \\
\text { mg protein } \cdot \text { min }\end{array}$ \\
\hline Strain 634b & $32.11 \pm 2.24$ & $5.66 \pm 0.34$ \\
Maxim XL + strain 634b & $24.13 \pm 1.62^{\#}$ & $4.35 \pm 0.26^{\ddagger}$ \\
Standak Top + strain 634b & $35.16 \pm 2.54^{\neq}$ & $3.65 \pm 0.22^{\#}$ \\
Strain 604k & $780.14 \pm 52.44$ & $2.11 \pm 0.12$ \\
Maxim XL + strain 604k & $410.23 \pm 21.82^{\text {×xx }}$ & $2.62 \pm 0.16$ \\
Standak Top + strain 604k & $530.44 \pm 33.74^{\text {×xx }}$ & $4.82 \pm 0.28^{\text {×x }}$ \\
\hline
\end{tabular}

Note: see Table 1.

Treatment of soybean seeds with fungicides together with the inactive rhizobia strain $604 \mathrm{k}$ induced a decrease in the activity of guaiacol peroxidase in root nodules by $47.4 \%$ (Maxim XL) and 32.1\% (Standak Top). At the same time, we did not detect significant changes in the activity of the enzyme in soybean root nodules inoculated with the rhizobia $634 \mathrm{~b}$ active strain for the action of fungicidal preparations.

Pre-treatment of soybean seeds with fungicides, in combination with inoculation of the inactive strain of rhizobium $604 \mathrm{k}$, led to an increase in the activity of polyphenol oxidase in root nodules, especially in the case of Standak Top by $128.4 \%$. In plants whose seeds were treated with fungicides together with the active strain $634 \mathrm{~b}$, the decrease in the activity of polyphenol oxidase in the root nodules by $23.1 \%$ (Maxim XL) and 35.5\% (Standak Top) was observed.

In the symbiotic system formed with the participation of soybean plants and the inactive strain of the rhizobium $604 \mathrm{k}$ together with the treatment of seeds with fungicide Maxim XL we fixed reduction of the process of nodulation into the stage of third true leaf, as evidenced by a decrease in the number of root nodules (by $41.2 \%$ ) and their mass (by $18.0 \%$ ) (Table 4). 
When seeds were treated with the Standak Top fungicide together with the $604 \mathrm{k}$ inoculum, an increase in the number of root nodules by $35.9 \%$ was observed during the stage of the second true leaf, which decreased by $29.8 \%$ during the stage of third true leaf. At the same time, the mass of root nodules in this variant of the experiment was almost at the level of plants without fungicide treatment.

In the symbiotic system formed with soybean and active strain 634b, the treatment of seeds with fungicide Maxim XL resulted in an increase in the number of nodules on the plant roots in the stage of the third true leaf, while the effects of the Standak Top showed an increase in their number in the stages of second and third true leaves. At the same time,

\section{Table 4}

Influence of fungicides on the formation of symbiotic apparatus of soybeans inoculated by B. japonicum $(\mathrm{x} \pm \mathrm{SE}, \mathrm{n}=8)$ the mass of root nodules in variants with treatment an inoculum (strain 634b) and fungicides was at the level of inoculated plants.

It was found that pre-treatment of seeds with fungicide Maxim XL together with an inoculum (strain 634b) contributed to an increase in the total nitrogenase activity of the root nodules by $39.2-35.7 \%$ in the stages of second and third true leaves, whereas their specific nitrogenase activity increased by $24.1-38.7 \%$ (Fig. 1). Treatment of seeds with fungicide Standak Top together with an inoculum (strain 634b) also resulted in an increase in both the total by $56.8-42.9 \%$ and specific (by 46.4 $46.1 \%$ ) nitrogenase activity of the symbiotic apparatus respectively in the stages of second and third true leaves.

\begin{tabular}{|c|c|c|c|c|c|c|}
\hline \multirow{3}{*}{ Variants } & \multicolumn{6}{|c|}{ Stages of ontogenesis } \\
\hline & \multicolumn{2}{|c|}{ first true leaf } & \multicolumn{2}{|c|}{ second true leaf } & \multicolumn{2}{|c|}{ third true leaf } \\
\hline & number, pc. / plant & mass, mg / plant & number, pc. / plant & mass, mg / plant & number, pc. / plant & mass, mg / plant \\
\hline Strain 634b & $12.11 \pm 0.78$ & $22.12 \pm 1.54$ & $16.81 \pm 1.17$ & $71.23 \pm 4.98$ & $17.62 \pm 1.12$ & $191.14 \pm 13.35$ \\
\hline Maxim XL + strain 634b & $12.42 \pm 0.72$ & $21.11 \pm 1.31^{\neq}$ & $14.42 \pm 0.86^{\#}$ & $72.22 \pm 5.11^{\neq}$ & $24.24 \pm 1.69^{\# \#}$ & $182.22 \pm 12.73^{\neq}$ \\
\hline Standak Top + strain 634b & $13.51 \pm 0.82^{\neq}$ & $21.14 \pm 1.33^{\neq}$ & $18.25 \pm 1.12^{\#}$ & $71.42 \pm 5.23$ & $18.82 \pm 1.16^{\ddagger}$ & $181.16 \pm 12.64^{\neq}$ \\
\hline Strain $604 \kappa$ & $17.33 \pm 1.21$ & $32.22 \pm 2.25$ & $22.88 \pm 1.62$ & $52.22 \pm 3.61$ & $59.62 \pm 3.57$ & $134.33 \pm 9.43$ \\
\hline Maxim XL + strain 604k & $18.33 \pm 1.28^{\times}$ & $33.54 \pm 2.15^{\times}$ & $29.21 \pm 2.15^{\times \times}$ & $61.56 \pm 4.22^{x \times}$ & $35.12 \pm 2.45^{\mathrm{x \times x}}$ & $110.12 \pm 8.72^{\times \times x}$ \\
\hline Standak Top + strain $604 \mathrm{k}$ & $17.61 \pm 1.26$ & $22.23 \pm 1.23^{\mathrm{xxx}}$ & $31.11 \pm 2.16^{\mathrm{x}}$ & $87.12 \pm 5.71^{\times \times \times}$ & $41.83 \pm 2.51^{x \times}$ & $133.24 \pm 9.31$ \\
\hline
\end{tabular}

Note: see Table 1.
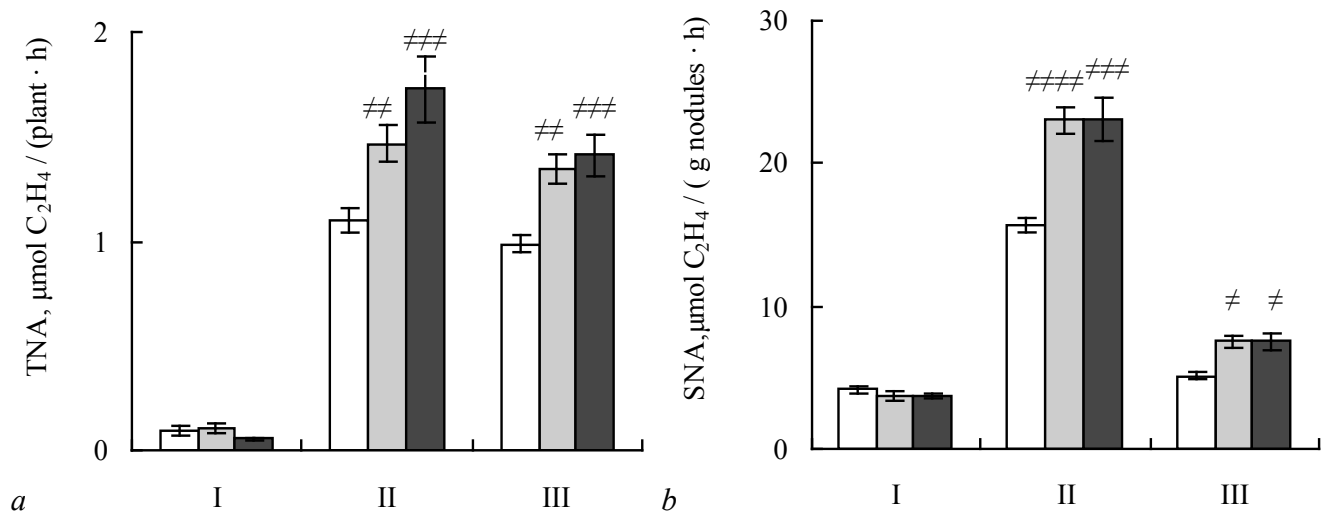

Fig. 1. Influence of fungicides on the total TNA $(a)$ and specific SNA $(b)$ nitrogenase activity of soybean symbiotic apparatus by inoculated B. japonicum: the colour of the bars in the diagram is filled in according to the variants: white - strain $634 \mathrm{~b}$, grey - Maxim XL + strain $634 \mathrm{~b}$, black - Standak Top + strain 634b; stages of ontogenesis: I - the first true leaf, II - the second true leaf, III - the third true leaf $(x \pm S E, n=8)$; the data compared with the control (strain 634b) are reliable at ${ }^{\neq}-\mathrm{P}<0.05,{ }^{\#}-\mathrm{P}<0.01,{ }^{\#}-\mathrm{P}<0.001$

\section{Discussion}

Phenolic compounds play an important role in legume-rhizobium symbiosis, since they not only induce the onset of symbiosis as signals mediators for the actions of Nod-factors, but also affect the redistribution of auxin, thus controlling the formation of nodules, and also remain regulators of the physiological state of the symbiotic system as at the stages of active nitrogen fixation and aging of nodules (Pourcel et al., 2007; Keet et al., 2017). A study of the activity of polyphenol oxidase in root nodules suggests a possible connection of the enzyme with the properties of rhizobia virulence. Scientists have found that the activity of polyphenol oxidase in symbiotic systems formed with the participation of highly virulent mutants was higher compared with the middle virulence mutants (Kots et al., 2010). At the same time, the activity of the enzyme in soybean root nodules formed by low-virulent mutants had the lowest level of enzymatic activity.

It was suggested that the high level of peroxidase activity in soybeans, inoculated with $B$. japonicum, indicates a possible change in the phytohormonal balance of the symbiotic system (Fedorova et al., 1992). Evidence of the special role of peroxidase in plant metabolism is its ability not only to carry out auxin oxidative degradation, but also to participate in a number of other reactions: photosynthesis, phenolic catabolism (oxidation of flavonoids), cell wall lignification, and general biological oxidation processes (Kartashova et al., 2000; Rosa, 2018).
The analysis of the results showed that for the ineffective symbiosis of soybean plants and inactive strains of $604 \mathrm{k}$, the growth of the activity of polyphenol oxidase in the roots in the stage of the first and second true leaves, which was accompanied by activation of the processes of nodulation at the roots of plants, is characteristic. With the symbiotic system formed with the participation of soybeans and the active strain of rhizobia $634 \mathrm{~b}$ an increased level of polyphenol oxidase in the roots was noted in the the stages of the seedlings' leaves, but this pattern was not continued at the next the stages of ontogenesis. At the same time, no significant changes in guaiacol peroxidase activity were detected in the roots of plants inoculated with rhizobia strain $634 \mathrm{~b}$ during the early stages of the ontogenesis of soybean to second true leaf stages, when the activity of the enzyme decreased markedly. Such changes were accompanied by the appearance of nodules on the roots, which actively fixed the molecular nitrogen of the atmosphere.

It was recorded that in the ineffective symbiotic system, application of seed treatment with fungicides led to an increase in the activity of guaiacol peroxidase in the roots during the early stages of the vegetation season of soybeans to the second true leaf. At the same time, the activity of polyphenol oxidase in the roots decreased in the stage of the second true leaf. Such changes in the activity of enzymes occurred against the background of a significant increase in the process of nodulation in the roots of plants in the stage of the second true leaf in variants with a common treatment with rhizobia (strain 604k) and fungicides. 
In an effective symbiotic system, the application of seed treatment with fungicides led to a slight increase in the activity of guaiacol peroxidase in the roots, especially in the stages of seedlings and primordial leaves, as well as increased activity of polyphenol oxidase by the action of Standak Top and the absence of significant changes in the activity of the enzyme under the action of Maxim during soybean growth. This occurred along with an increase in the nitrogenase activity of the symbiotic soybean apparatus during the combined treatment of rhizobia and fungicides. A low level of activity of guaiacol peroxidase and increased polyphenol oxidase in soybean root nodules inoculated with rhizobium $634 \mathrm{~b}$ active strain were detected, compared with plants inoculated with an inactive strain $604 \mathrm{k}$.

When using fungicides in an ineffective symbiotic system, a decrease in the activity of guaiacol peroxidase and an increase in polyphenol oxidase in root nodules in the stage of third true leaf was observed, accompanied by inhibition of nodulation processes in plant roots.

At the same time, in the effective symbiotic system for the action of fungicides, insignificant changes were observed in the level of guaiacol peroxidase activity and a decrease in the activity of polyphenol oxidase in soybean root nodules, which was accompanied by an increase in nodulation and nitrogen fixation processes.

The discovery of legume-rhizobium interaction mechanisms is associated with the overcoming of the host plant's defense systems by bacteria (Beatty \& Good, 2011). It has been proven (Pauly et al., 2006; Glyanko, 2016) that the main participants in the recognition process of partners of symbiosis are, on the one hand, rhizobia lipochitooligosaccharides (Nod-factors), and on the other hand, the receptor-like kinases (RLK) legumes. Nod-factors are synthesized by rhizobia bacteria as a result of the expression of nod-genes, which initiate the synthesis of phenolic compounds secreted by the plant into the rhizosphere. Nodfactors are perceived by the plant's epidermal cells, on the plasma membrane of which the complex of receptor-like kinases is located. The chemical recognition of partners in the early stages of legume-rhizobium symbiosis leads to the activation of symbiotic pathways in the host plant associated with infection and bulbous formation (Murray, 2011) and, apparently, with the suppression of protective systems (Gourion et al., 2015). This is the first reaction of the host plant to invasion of rhizobia: the bacterial component in the form of the Nod-factor (MAMP-pattern) and the plant component in the form of receptor-like kinases, located on the plasmalemma of the cell (LysM RLK) and intracellular (LRR RLK) (Ferguson et al., 2010).

It has been proved that when establishing the molecular interaction between the macro- and microsymbionts, the enhanced generation of reactive oxygen species occurs as a result of the activation of the host plant's defense reactions to infection (Glyanko, 2016). Modulation of the macrosymbiont metabolism (a legume plant) under the influence of microsymbiont (rhizobia), which is expressed in the accumulation of reactive oxygen species, indicates a hypersensitive response of plant cells. This indicates the possible participation of reactive oxygen species in the regulation of infection processes and nodulation in the interaction of symbionts. In this case, the macrosymbiote develops a "systemic induced resistance" that manifests itself in non-legume plants when infected with non-pathogenic microorganisms (Pieterse et al., 1998). Therefore, it is believed that protective reactions are similar to the initial phases of the interaction of plants with phytopathogens (Parniske, 2000; Manchanda \& Garg, 2007; Ivanov et al., 2012). The legume-rhizobium interaction leads a host plant to local reactions that occur with repression or induction of defense mechanisms and is accompanied by the generation of reactive oxygen species, increased activity of oxidative and other enzymes (peroxidase, catalase, polyphenol oxidase, superoxide dismutase), accumulation of phenolic compounds, and also by increase in the activity of antioxidant protection, which prevents the destructive action of free radicals (Pauly et al., 2006; Mittler et al., 2011; Damiani et al., 2016; Glyanko, 2016; Mittler, 2017).

It is believed that a high level of polyphenol oxidase activity in nitrogen-fixing nodules may indicate the similarity of some reactions - the response of plants to infection by pathogenic microorganisms and rhizobium inoculation (Soto et al., 2006; Pradhan et al., 2018; Shimna \& Thangavel, 2018). However, in the nodules, the result of these reactions is not the inactivation of the microorganism, but the regulation of its reproduction and metabolic activity in the symbiosomes. In the literature, the peroxidase reaction is considered as the response to the penetration of rhizobia into a plant cell (Zhiznevskaya et al., 2001). At the same time, it is believed that peroxidases can carry enough information about the physiological state of the plant and serve as a criterion of resistance to the action of stress factors of biotic and abiotic nature (Chen \& Vierling, 2000; Kumar et al., 2017).

Publications of recent years indicate that active research has been conducted on the use of fungicidal preparations to regulate plant metabolism and increase their stress tolerance to the action of biotic factors (Dicheng et al., 2018; Standish et al., 2018; Tackenberg et al., 2018). It has been proven that soybean plants with active symbiotic apparatus are more resistant to damage from a wide range of diseases, and that a clear combination of all measures aimed at optimizing the symbiosis process contributes to the formation of a powerful symbiotic apparatus, improving the phytosanitary condition of crops, improving soil fertility and obtaining high soybean yields with better quality indicators (Mikolaevsky et al., 2017). On the other hand, scientists have shown that pesticides can affect inhibition of the flavonoid Nod receptor, inducing the inhibition of the synthesis and secretion of flavonoid substances produced by the plant, thereby disrupting legume-rhizobium signaling (Bikrol et al., 2005; Fox et al., 2007; Araujo et al., 2017; Standish et al., 2018). In addition, it was found that each of the studied chemicals competitively limited the activation of the Nod gene factor, depending on its concentration and inhibitory action. Aspects of the molecular interaction of symbiosis partners in the early stages are well known, but an integrated approach to the use of this knowledge in order to regulate and improve the processes of nodulation and nitrogen fixation under the influence of stress factors is still unclear and needs further careful study.

\section{Conclusions}

The effective symbiotic system formed with the participation of soybean plants and the active strain rhizobia $634 \mathrm{~b}$ is characterized by a high level of polyphenol oxidase activity and low guaiacol peroxidase in roots and root nodules in the stages of second and third true leaves. Such changes in the activity of enzymes occurred along with the formation of nodules, which actively fixed the molecular nitrogen of the atmosphere. An ineffective symbiotic system (strain 604k) is characterized by an elevated level of polyphenol oxidase activity in the roots and guaiacol peroxidase in the root nodules, which is accompanied by activation of the process of nodulation. Treatment of soybean seeds with fungicides in an effective symbiotic system leads to a change in the activity of the enzymes of the phenolic metabolism, which induced adaptive changes in plant metabolism and growth of nitrogenase activity of the root nodules. The recorded changes in the activity of both enzymes for the action of fungicides in the ineffective symbiotic system can be considered as a kind of response of the plant to the treatment and are observed along with the reduction of the processes of nodulation into the stage of the third true leaf.

\section{References}

Andrews, M., \& Andrews, M. E. (2017). Specificity in legume-rhizobia symbioses. International Journal of Molecular Science, 18(4), 1-39.

Araji, S., Grammer, T. A., \& Gertzen, R. (2014). Novel roles for the polyphenol oxidase enzyme in secondary metabolism and the regulation of cell death in walnut. Plant Physiology, 164(3), 1191-1203.

Argawa, A., \& Mnalku, A. (2017). Symbiotic effectiveness of Rhizobium leguminosarum bv. vicieae isolated from major highland pulses on field pea (Pisum sativum L.) in soil with abundant rhizobial population. Annals of Agrarian Science, $15,410-419$.

Beatly, P. H., \& Good, A. G. (2011). Future prospects for cereals that fix nitrogen. Science, 333, 416-417.

Bikrol, A., Saxena, N., \& Singh, K. (2005). Response of Glycine max in relation to nitrogen fixation as influenced by fungicide seed treatment. African Journal of Biotechnology, 4(7), 667-671.

Bradford, M. A. (1976). Rapid and sensitive method for the quantitation of the microgram quantities of protein utilising: The principle of protein - dye binding. Analytical Biochemistry, 72, 248-254. 
Chang, C., Damiani, I., Puppo, A., \& Frendo, P. (2009). Redox changes during the legume-rhizobium symbiosis. Molecular in Plant, 2(3), 370-377.

Chen, H., \& Vierling, R. A. (2000). Molecular cloning and characterization of soybean peroxidase gene families. Plant Science, 150(2), 129-137.

Damiani, I., Pauly, N., Puppo, A., Brouquisse, R., \& Boscar, A. (2016). Reactive oxygen species and nitric oxide control early steps of the legume - rhizobium symbiotic. Frontiers in Plant Science, 7, 1-8.

Desbrosses, G. J., \& Stougaard, J. (2011). Root nodulation: A paradigm for how plant-microbe symbiosis influences host developmental pathways. Cell Host and Microbe, 10, 348-358.

Egley, G. H., Paul, R. N., Vaughn, K. C., \& Duke, S. O. (1983). Role of peroxidase in the development of water impermeable seed coats in Sida sprinosa $\mathrm{L}$. Planta, 157(1), 224-232.

Fedorova, E. E., Zhiznevskaya, G. Y., Kalibernaya, Z. V., Artemenko, E. N., Izmajlov, S. F., \& Guskov, A. V. (2000). Metabolizm IUK pri ustanovlenii simbioza mezhdu Phaseolus vulgaris i Rhizobium phaseoli [Metabolism of IOA with the establishment of symbiosis between Phaseolus vulgaris and Rhizobium phaseoli]. Fiziologiya Rastenij, 47(2), 231-235 (in Russian).

Ferguson, B. J., Indrasumunar, A., Hayashi, S., Lin, M. H., Lin, Y. H., Reid, D. E. \& Gresshoff, P. M. (2010). Molecular analysis of legume nodule development and autoregulation. Journal of Integrative Plant Biology, 52(1), 61-76.

Fox, J. E., Gulledge, J., Engelhaupt, E., Burow, M. E., \& McLachlan, J. A. (2007) Pecticides reduce symbiotic efficiency of nitrogen-fixing rhizobia and hos plants. Proceeding of the National Academy of Sciences, 104(24), 10282-10287.

Glyanko, A. K. (2016). Zashitnye sistemy bobovogo rasteniya pri inficirovanii rizobiyami [The protective system of a legume plant when infected with rhizobia]. Byuleten Harkovskogo Nacionalnogo Agranogo Universiteta, Seriya Biologiya, 37, 63-77 (in Russian).

Gourion, B., Berrabah, F., Ratet, P., \& Stacey, G. (2015). Rhizobium-legume symbioses: The crucial role of plant immunity. Trends in Plant Science, 20(3), 186194.

Hardy, R. W. F., Holsten, R. D., Jackson, E. K., \& Burns, R. C. (1968). The acetylene-ethylene assay for nitrogen fixation: Laboratory and field evalution. Plant Physiology, 43(8), 1185-1207.

Ivanov, S., Fedorova, E. E., Limpens, E., De Mita, S., Genre, A., Bonfante, P., \& Bisseling, T. (2012). Rhizobium-legume symbiosis shares an exocytotic pathway required for arbuscule formation. Proceeding of the National Academy of Sciences, 109(21), 8316-8321.

Jemo, M., Sulieman, S., Bekkaoui, F., Oluwatosin, A. K., Olomide, A. H., Allah, E. F. A., Alqarawi, A. A., \& Tran, L. S. P. (2017). Comparative analysis of the combined effects of different water and phosphate levels on growth and biological nitrogen fixation of nine cowpea varieties. Frontiers in Plant Science, 2111, 1-16.

Kamal, A., Gasmalla, M. A., \& Alyousef, H. (2015). Efficient methods for polyphenol oxidase production. International Journal of Nutrition and Food Sciences, 4(6), 656-659.

Kartashova, E. R., Rudenskaya, G. N., \& Yurina, E. V. (2000). Polifunkcionalnost rastitelnyh peroksidaz $\mathrm{i}$ ih praktieskoe ispolzovanie [Polyfunctionality of plant peroxidases and their practical use]. Selskohozyajstvennaya Biologiya, 5, 63-70 (in Russian).

Keet, J. H., Ellis, A. G., Hui, C., \& Le Roux, J. J. (2017). Legume-rhizobium symbiotic promiscuity and effectiveness do not affect plant invasiveness. South African Journal of Botany, 109, 341.

Kosslak, R. M., Bookland, R., Barkei, J., Paaeren, E. I., \& Appelbaum E. R. (1987). Induction of Bradyrhizobium japonicum common nod genes by isoflavones isolated from Glicine max. Proceeding of the National Academy of Sciences, 82, 7428-7432.

Kots, S. Y., Morgun, V. V., Patyka, V. F., Datsenko, V. K., Krugova, E. D., Kirichenko, E. V., Melnikova, N. N., \& Mikhalkiv, L. M. (2010). Biologicheskaya fiksaciya azota: Bobovo-rizobialnyj simbioz [Biological fixation of nitrogen: Legume-rhizobium symbiosis]. Logos, Kyiv (in Ukrainian).

Kumar, P., Kumar, R., \& Ansari, S. A. (2017). Nitrate reductase and peroxidase activity in growth and productivity of Santalum album L. Tropical Plant Research, 4(1), 90-94.

Kuvalekar, A., Redkar, A., Gandhe, K., \& Harsulkar, A. (2011). Peroxidase and polyphenol oxidase activities in compatible host-pathogen interaction in Jasminum officinale and Uromyces hobsoni: Insights into susceptibility of host. New Zealand Journal of Botany, 49(3), 351-359.
Laranjo, M., Alexandre, A., \& Oliveira, S. (2014). Legume growth-promoting rhizobia: An overview on the Mesorhizobium genus? Microbiological Research, $169,2-17$.

Ma, D., Zhu, J., He, L., Cui, K., Mu, W., \& Liu, F. (2018). Baseline sensitivity of Phytophthora capsici to the strobilurin fungicide benzothiostrobin and the efficacy of this fungicide. European Journal of Plant Pathology, 152(3), 723-733.

Manchanda, G., \& Garg, N. (2007). Endomycorrhizal and rhizobial symbiosis: How much do they share? Journal of Plant Interactions, 2(2), 79-88.

McCormick, S. (2018). Rhizobial strain-dependent restriction of nitrogen fixation in a legume-Rhizobium symbiosis. The Plant Journal, 93(1), 3-4.

Mikolaevsky, V., Sirenko, V., \& Titova, L. (2017). Vliyanie pereposivnoj bakterizacii semyan na razvitie boleznej i urozhajnost soi [Influence of re-bacterization of seeds on the development of diseases and yield of soybean]. Stiinta Agricola, 1, 55-59 (in Ukrainian).

Mishra, B. B., \& Gautam, S. (2016). Polyphenol oxidases: Biochemical and molecular characterization, distribution, role and its control. Enzyme Engineering, $5(1), 1-9$.

Mittler, R. (2017). ROS are good. Trends in Plant Science, 22(1), 11-19.

Mittler, R., Vanderauwera, S., Suzuki, N., Miller, G., Tognetti, V. B., Vandepoele, K., Gollery, M., Shulaev, V., \& Van Breusegem, F. (2011). ROS signaling: The new wave? Trends in Plant Science, 16(6), 300-309.

Murray, J. D. (2011). Invasion by invitation: Rhizobial infection in legumes. Molecular Plant-Microbe Interactions, 24(6), 631-639.

Novikova, T. I., \& Sidorova, K. K. (2003). Issledovanie fenolnogo sostava sortov i mutantnyh linij goroha, razlichayushihsya po simbioticheskoj aktivnosti [Study of the phenolic composition of varieties and mutant pea lines, differing in symbiotic activity]. Sibirskij Ekologicheskij Zhumal, 1, 101-106 (in Russian).

Panadare, D., \& Rathod, V. K. (2018). Extraction and purification of polyphenol oxidase: A review. Biocatalysis and Agricultural Biotechnolog, 14, 431-437.

Parniske, M. (2000). Intracellular accommodation of microbes by plants: A common developmental program for symbiosis and disease? Current Opinion Plant Biology, 3(4), 320-328.

Pauly, N., Pucciariello, C., Mandon, K., Innocenti, G., Jamet, A., Baudouin, E., Herouart, D., Frendo, P., \& Puppo, A. (2006). Reactive oxygen and nitrogen species and glutathione: Key players in the legume-Rhizobium symbiosis. Journal of Experimental Botany, 57(8), 1769-1776.

Pourcel, L., Routaboul, J., Cheynier, R., Lepiniec, L., \& Debeaujon, I. (2007). Flavanoid oxidation in plants: From biochemical properties to physiological functions. Trends Plant Science, 12(1), 29-36.

Pradhan, D., Sinclair, T., \& Alijani, K. (2018). Nitrogen fixation establishment during initial growth of grain legume species. Journal of Crop Improvement, 32(1), 50-58.

Rosa, E. (2017). Enhancing legume growing through sustainable cropping for protein supply. Science of Food and Agriculture, 97(13), 4271-4272.

Shimizu, M. M., \& Mazzafera, P. (2007). Polyphenoloxidase is induced by methyljasmonate and Meloidogyne javanica in soybean roots but is not involved in resistance. Nematology, 9(5), 625-634.

Shimna, A. K., \& Thangavel (2018). Polyphenol oxidase: Characterization, enzyme activity and antibacterial activity against bacterial pathogens. International Journal of Research in Ayurveda and Pharmacy, 9(2), 137-142.

Soto, M. J., Sanjua'n, J., \& Olivares, J. (2006). Rhizobia and plant-pathogenic bacteria: Common infection weapons. Microbiology, 152, 3167-3174.

Standish, J. R., Brenneman, T. B., \& Stevenson, K. L. (2018). Dynamics of fungicide sensitivity in Venturia effusa and fungicide efficacy under field conditions. Plant Disease, 102(8), 1606-1611.

Tackenberg, M., Volkmar, C., Schirrmann, M., Giebel, A., \& Dammer, K. H. (2018) Impact of sensor-controlled variable-rate fungicide application on yield, senescence and disease occurrence in winter wheat fields. Pest Management Science, 74(6), 1251-1258.

Taranto, F., Pasqualone, A., Mangini, G., Tripodi, P., Miazzi, M. M., Pavan, S., \& Montemurro, C. (2017). Polyphenol oxidases in crops: Biochemical, physiological and genetic aspects. International Journal of Molecular Science, 18(2), 2-16.

Yoruk, R., \& Marshall, M. (2003). Physicochemical properties and functional of plant polyphenol oxidase: A review. Journal of Food Biochemistry, 27(5), 361-422.

Zhiznevskaya, G. Y., Troitskaya, G. N., Borodenko, L. I., \& Izmaylov, S. F. (2001) Peroksidaza i katalaza v kornevyh klubenkah kormovyh bobov pri effektivnom i neeffektivnom simbioze s rizobiyami [Peroxidase and catalase in root nodules of fodder beans at effective and ineffective symbiosis with rhizobia] Fiziologiya i Biohimiya Kulturnyh Rastenij, 33(6), 285-290 (in Ukrainian). 